\title{
Bone and calcium markers in relation to cardiovascular risk in patients with osteoporosis
}

\author{
Carmen Gabriela Barbu' ${ }^{12}$, Suzana Florea ${ }^{1}$ \\ 1 Endocrinology Department, Elias Hospital, Bucharest, Romania \\ 2 "Carol Davila" University of Medicine and Pharmacy, Bucharest, Romania
}

Aim of the study was to evaluate the relationship between biochemical bone turnover markers, calcium homeostasis parameters and the cardiovascular risk in patients with osteoporosis.

Materials and methods. Subjects were 246 patients (mean age of 56.64) diagnosed with osteoporosis refered to the endocrine department of Elias Hospital, between 2009 and 2013, and who agreed with the terms of the study. Data collection consisted of clinical evaluation, physical exam and biochemical routine blood tests and hormones and the parameters of calcium homeostasis needed for differential diagnosis of osteoporosis. Osteoporosis was diagnosed based on the WHO criteria and metabolic syndrome based on the the IDF 2007 guidelines. In order to evaluate the relationship between calcium and bone parameters and cardiovascular risk, we used metabolic syndrome as the criteria to segregate the subjects in control group (without Mets) and study subjects (with Mets).

Results. Serum intact PTH levels were significantly higher in Mets group: 76.2 [40.8] pg/ml, comparing to 65.6 [42.8] $\mathrm{pg} / \mathrm{ml}$ in control group $(\mathrm{p}<0.01)$. No other calcium or bone biochemical marker (serum calcium, 24 hours calciuria, serum osteocalcin, $25 \mathrm{HO}$ vitamin $\mathrm{D}$, serum betacrosslaps) was significantly different across the study groups.

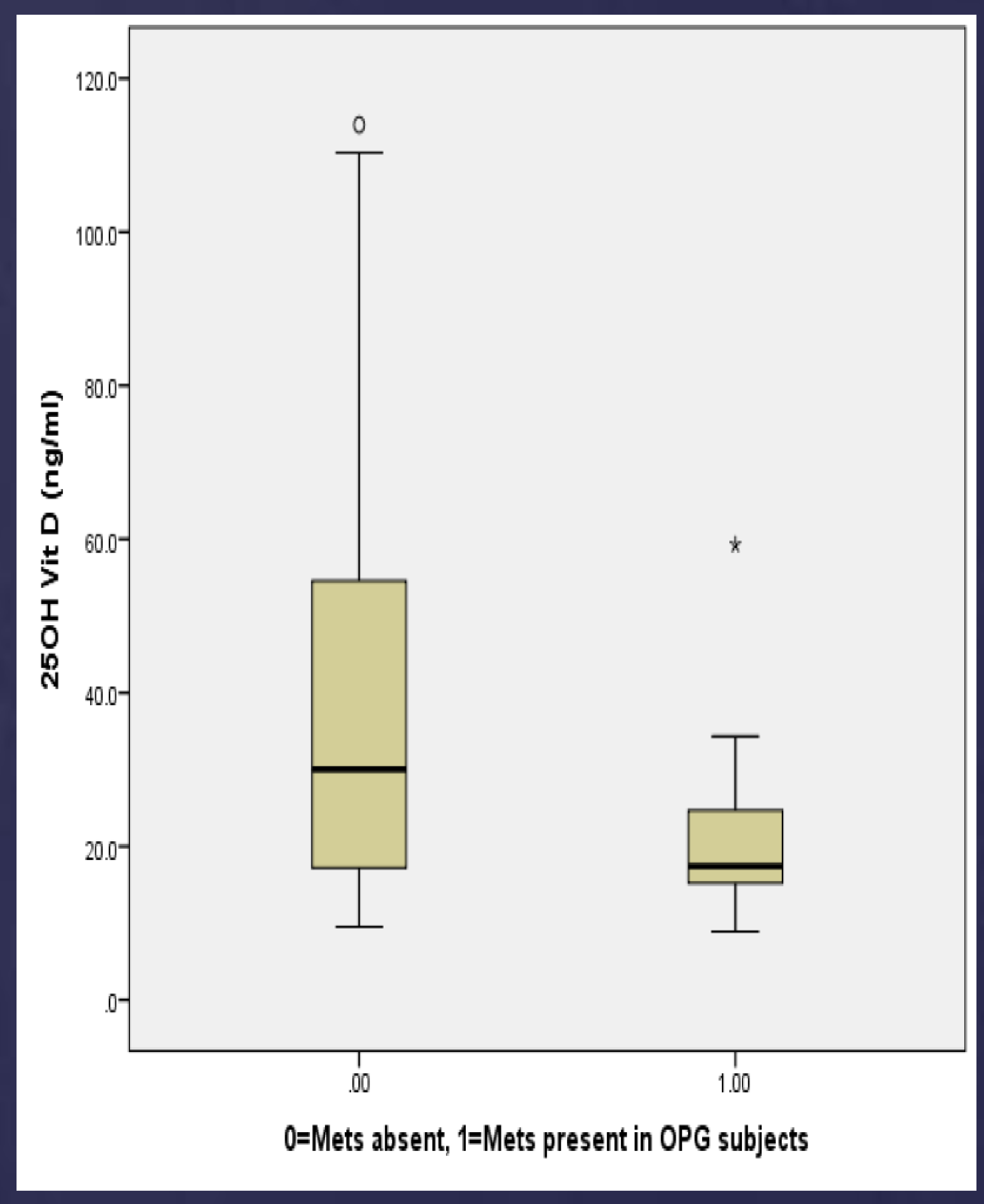

Conclusion. Hyperparathyroidism, either secondary or primary is frequent among patients with osteoporosis. Increased level of parathyroid hormone was found to be associated with increased risk in cardiovascular disease in our patients with osteoporosis suggesting that, beside the bone aspects, there may be also some other metabolic effects of the excess of the parathyroid hormone
Comparison between study subgroups according to the Mets presence criteria among: bone markers parameters.

\begin{tabular}{|l|l|l|l|}
\hline & $\begin{array}{l}\text { Control } \\
\text { group } \\
\text { Mets) }\end{array}$ & $\begin{array}{l}\text { Study group } \\
\text { (Mets } \\
\text { present) }\end{array}$ & \\
\hline Serum total & & & P value \\
Ca** (mg/dl) & $9.3(0.5)$ & $10(0.8)$ & NS** \\
\hline $\begin{array}{l}24 \quad \text { hrs urine } \\
\text { calcium* } \\
\text { (mg/24 hrs) }\end{array}$ & $158[151]$ & $118[168]$ & NS* \\
\hline $\begin{array}{l}\text { Total ALP* } \\
\text { (UI/L) }\end{array}$ & $87[90]$ & $134[109]$ & NS* \\
\hline iPTH* (pg/ml) & $77.2[13.3]$ & $80.6[16.9]$ & NS* \\
\hline $\begin{array}{l}\text { 25 HO Vit D* } \\
\text { (ng/ml) }\end{array}$ & $30[39]$ & $17.4[11.1]$ & $<0.01 *$ \\
\hline $\begin{array}{l}\text { Osteocalcin* } \\
\text { (ng/ml) }\end{array}$ & $10.4[12.4]$ & $10.1[10.1]$ & NS* \\
\hline $\begin{array}{l}\text { Crosslaps* } \\
\text { (ng/ml) }\end{array}$ & 0.448 & 0.132 & \\
\hline$*$ [0.137] & {$[0.389]$} & NS* \\
\hline
\end{tabular}

* Data expressed as median and interqurtile range; a Mann Whitney test result is displayed.

** Data expressed as mean and standard deviation; a Student $\mathrm{t}$ Test result is displayed 